\title{
Failure is not an Option: Parental Expectations of Nigerian Voluntary Immigrants to the United States \\ Dolapo Adeniji-Neill, PhD
}

\begin{abstract}
The purpose of this study was to explore the socio-cultural and educational contexts of parental expectations of Nigerian voluntary immigrants to the United States. Immigrant or voluntary minorities are people who have migrated essentially of their own volition to the United States, or any other nation, because they seek more economic mobility, or a better life in general, and/or political freedom (Ogbu, 1995). This case study sought an explanation for the success in education attributed to these new African immigrants and their children. This study investigated the relationship among three factors: (a) parental expectations,

(b) socio-cultural experiences, and (c) (adult) children's internalization of their parent's aspirations for them. The method of inquiry included phenomenological analysis on data collected through participants' topical life-histories (Giorgio, 1985). The results of the study represent the Nigerian immigrants' worldviews: a folk theory shaped by their cultural and life experiences. The common threads running throughout their responses are 'education is the number one priority, ' 'hard work,' 'effort begets luck,' and 'failure is not an option.' Nigerian culture had a strong influence on the upbringing and fulfillment of expectations for the children of the participants.
\end{abstract}

Parental expectations are various beliefs, assumptions, and aspirations that relate to, but are not limited to, the relationship of students to faculty, curriculum, discipline, culture, acculturation, and family composition as they contribute to children's school achievement. These beliefs and assumptions usually motivate parents to encourage their children's success in school (Carden, 2005; Foner, 2009; Li, 2004; Portes \& Rumbaut, 1990; Seginer, 1983; Waters \& Sykes, 2009; Zhou, 2009). Research on immigrant families has shown that immigrant status increases parental expectations (Ogbu, 1995; Li, 2004; Zhou, 2009). Studies by Patrikakou (1997) and Ethington (1991) suggest that parental expectations and student perceptions of parental attitude were essential in influencing students' academic expectations, thereby raising their academic achievement level. Englund, Luckner and Whaley (2004) found that parental expectations appear to be different from other definitions of parental involvement because parental expectations are beliefs, whereas, other measures of parental involvement center on actual behaviors, such as attending parent-teacher conferences or helping with homework. It is important to distinguish between these two types of constructs when looking into parental influences on academic achievement or attainment. Li; Foner; Waters and Sykes and Zhou posit that interpersonal expectations play an essential role in everyone's life, and that parental expectations are universal. However, expectations may undergo some fundamental changes when people reside in a different culture from that in which they were born, due to the influences of the host culture. This was evident in the responses of the participants of this study (see discussion).

Statistics from the US Census Bureau (2000) indicate that many voluntary immigrants from Nigeria came to the United States with college degrees, and earned postgraduate degrees while in the United States. The United States Census data indicated that Africans also have the highest educational degrees of any immigrant group in the United States, with even higher levels of educational completion than the Asian American 'model minority'. In addition, educational success of the African immigrants goes beyond the first generation (Johnson, 2005). This is very fortunate for the host country, but it contributes the Nigeria 'brain-drain'. In 1997, 19.4 per cent of all adult African immigrants in the United States held a graduate degree, compared to 8.1 per cent of adult Whites and 3.8 per cent of adult Blacks in the United States, respectively (see Table 1). This information suggests that America has an equally large achievement gap between Whites and African voluntary immigrants as they do 
Table 1.

English Fluency and Education of U. S. Immigrants

\begin{tabular}{|l|l|l|l|l|l|l|}
\hline Areas & $\begin{array}{l}\text { US } \\
\text { population }\end{array}$ & $\begin{array}{l}\text { All } \\
\text { immigrants }\end{array}$ & $\begin{array}{l}\text { African } \\
\text { immigrants }\end{array}$ & $\begin{array}{l}\text { Asian } \\
\text { Americans }\end{array}$ & $\begin{array}{l}\text { Europe, } \\
\text { Russia \& } \\
\text { Canada }\end{array}$ & $\begin{array}{l}\text { Latin, South } \\
\text { America \& } \\
\text { Caribbean }\end{array}$ \\
\hline Not fluent in English & $0.6 \%$ & $30.5 \%$ & $7.6 \%$ & $23.4 \%$ & $11.5 \%$ & $44.0 \%$ \\
\hline Less than high school & $17.1 \%$ & $39.1 \%$ & $12.1 \%$ & $21.2 \%$ & $23.5 \%$ & $57.4 \%$ \\
\hline College degree & $23.1 \%$ & $23.3 \%$ & $43.8 \%$ & $42.5 \%$ & $28.9 \%$ & $9.1 \%$ \\
\hline Advanced degree & $2.6 \%$ & $4.2 \%$ & $8.2 \%$ & $6.8 \%$ & $5.8 \%$ & $1.9 \%$ \\
\hline Source: US Census, 2000.
\end{tabular}

between White and Black Americans ("African Immigrants in the United States ..... 1999-2000).

\section{Income levels}

According to the 2000 US Census, income levels among African immigrants are typically higher than Black Americans. This can be attributed to the higher education levels. However, Africans still earn on average less than Asian and European Americans with similar or lower levels of education, suggesting ongoing discrimination (Hersh, cited in Wolf, 2007). Most recent Nigerian immigrants came to the United States to pursue educational opportunities in both undergraduate and postgraduate institutions. Nearly all of these immigrants came from the southern part of the country. They are mostly the Igbo and Yoruba ethnic groups. Due to Nigeria's economic woes, many did not return to Nigeria after they completed their educational goals and began to raise their families as first generation American citizens. US Census Bureau data show a 368\% increase in the Nigerian population in the United States from 1990 to 2000 , with a numerical increase from 35,300 to 165,481 . It is estimated that the current population of African immigrants is over 600,000. Many immigrants from Africa live in major cities in the United States. Countries with the most immigrants to the US are Nigeria, Ghana, Ethiopia, Eritrea, Egypt, Somalia, and South Africa. Some of them came from Angola, Cape Verde, Mozambique, Equatorial Guinea, Kenya, and Cameroon. Many migrated here for a better economic and political life.

\section{Research questions}

This study examines, in particular, how socio-culturally and psychologically lived experiences affect parental expectations in education and their children's internalization of such expectations. My overarching research questions are: (1) What are Nigerian voluntary immigrants' parental expectations for their children's education? (2) What role do socio-cultural contexts play in Nigerian parents' expectations for their children's education? (3) How have the adult children of Nigerian immigrants internalized their parents' expectations?

\section{Literature Review}

Educational expectations, parental involvement, and parenting styles represent specific value systems that can be transmitted to the child and may be expected to influence the children's educational attainment (Pearce, 2006). Regarding these values, when education is seen as a path to social mobility, more energy is devoted towards academic achievement and attainment (Ogbu, 1995; Pearce, 2006; Zhou, 2009). These beliefs and assumptions usually motivate parents to encourage their children's success in school (Carden, 2005; Li, 2004; Seginer, 1983; Zhou, 2009). Research on immigrant families has shown that voluntary minority status increases parental expectation (Ethington, 1991; Li; Ogbu). A study by Patrikakou (1997) suggests that parental expectations and student perceptions of parental 
attitude were essential in lifting students' academic expectations, thereby raising their academic achievement levels.

Cultural context affected the nature of the correlation between student achievement and parentstudent discussion about school (Desimone, 1999). Several research studies document strong relationships between achievement and parent-child communication and the parent-child relationship (Becher, 1984; Eccles \& Harold, 1993; Lee, 1994; Muller, 1993; Sui-Chu \& Williams, 1996). However, a comparison across models found that student-reported discussion was a significantly better predictor for Whites than for Asians, Blacks, or Hispanics and for middle-income students compared with lowincome students.

In their research (Epstein, 1995; Halle, Kurtz-Costes \& Mahoney, 1997; Li, 2004; Losh \& Tavani, 2003; Moss \& St. Laurent, 2001; Portes \& Rumbaut, 2001; Stevenson \& Baker, 1987) show that the attitude parents display relating to expectations for school achievement have significant impact on their children's behavior. Moreover, Stevenson \& Lee (1990) indicate that parents who believe that their children's performances are determined by their abilities tend to participate less frequently in their children's school careers than those parents who believe their children's performance is determined by effort.

During the 1970 s and 1980s, the Black-White gap in standardized scores narrowed by some $20 \%$, while the 1990 saw this trend reverse and the gap again widen. Research on the achievement gap and racial inequality cited cultural and structural elements as factors. This discourse remains primarily focused on the persistent Black-White gap across the spectrum of achievement and attainment. Although Chinese Americans have been recognized as a minority group that has achieved and attained at a higher level, it is important to also note that African immigrants are currently out-performing Whites and all other immigrants to the United States (Le, 2007; Rimmer and Arenson, 2004; United States Census, 2000). By gaining a better understanding of the factors that aid some foreign-born Africans in realizing academic success, we can identify methods for ameliorating the situation among underachieving groups.

A great deal of qualitative research has explored achievement among Chinese Americans (e.g., Li, 2004; Pearce, 2006; Siu \& Feldman, 1995; Zhou, 2009). However, while both structural and cultural explanations from this perspective inform our understanding of the context of Chinese American educational achievement, quantitative studies have not come down conclusively on either side of the structural-cultural debate. The general area of achievement has received considerable attention in the literature, with various studies focusing on achievement (Pearce, 2006; Pearce \& Lin 2005; Portes \& Zady, 1996), achievement loss (Alspaugh, 1998; Alspaugh \& Harting, 1995), and the achievement gap (Chen, C \& Stevenson, 1995; Chen, X., 1996; Rosenthal \& Feldman, 1991). Recent literature has also given considerable attention to school transitions (e.g., Alspaugh, 1998; Eccles, Wigfield, Midgley, Reuman, Maclver \& Fieldlaufer, 1993; Pearce, 2006). Alspaugh and Harting (1995) cite sociostructural factors as explaining achievement loss and dropout rates. Success of new minorities in the education field, although not conclusive, may be attributed to cultural and sociocultural factors. Various studies have focused on achievement and attainment (Pearce, 2006; Pearce \& Lin, 2005; Portes \& Zady, 1996). Parental expectations in students' educational success have also been explained through the frameworks of cultural capital theory and socio structural theory (Bourdieu, 1977a; Bourdieu \& Passeron, 1977; Pearce, 2006). Waters (2000) studied the success of West Indians in contrast to many African Americans; she found that the sociocultural reality of American race relations and economic disadvantage is similar within both communities among the working class and poor immigrants. And that the barriers the poor and working class immigrants face soon dampen the enthusiasm and belief of education as the engine to success. On the contrary, Pearce notes that, America has changed in fifty years concerning structural changes that advance greater economic, educational, and social parity among all members of our society. Groups like African Americans and Latinos/as have made 
greater progress than students in all fields, especially in the field of education.

Cultural explanations for parental expectations used in this study assume that parental beliefs and values are crucial to immigrant students' educational achievement. Culture defines people and their affiliation to groups; a break from culture represents a break from one's community and identity (Fordham \& Ogbu, 1986; Kim, 2004; Pearce 2006; Zhou, 2009). Cultural factors may allow individuals to excel, or they may also serve as deterrents (Portes \& Zady, 1996). Researchers have cited cultural resources that include hard work, frugality, and entrepreneurship of non-English speaking immigrants from Europe as responsible for their successes (Sowell, 1981); this is also true of Nigerian immigrants in this study. Cultural explanation in this study identified the elements in the immigrant culture that enable achievement. It also identified less beneficial elements of the culture; this is not to apportion blame to the families in this study, but to identify factors that are both positive and negative that support parental expectations in students' education. In this study all participants acknowledged that there are tensions inherent to being a new comer in a country as well as racism but, despite these negative factors, they were able to succeed in their chosen endeavors. I would also posit that indigenous education as lived experiences influenced the parent participants of this study because they consistently referenced this during the interviews.

\section{Indigenous Education in Africa (How lived experiences of participants influence their parental expectations)}

Onwauchi (1972) states that, in all societies every child is endowed with an innate quality of mind and body. The child acquires education through the process of socialization and the cultural mode of behavior. He defines culture as 'the sum total of the integrated learned behavior patterns characteristic of members of a society'. Culture is the people's way of life, their social organization, and economic patterns, including feelings shared by members of the community. Culture is learned, not biologically inherited. People are products of their culture. It is through the pursuit of cultural norms and values that individuals give meaning to their lives. Norms and values are socially standardized concepts of what is acceptable and what is unacceptable. These differ from place to place. When two cultures meet, it is understandable that this will result in some changes to both cultures; however, the new cultural values born of the marriage of the two must be properly adjusted to existing cultural fabrics in the other to be fully beneficial. Several studies (Mbiti, 1990; Menkiti, 1984; Onwauchi, 1972; Tedla, 1992; Wiredu, 1977) indicate indigenous African learning is inseparable from the peoples' daily lives. Indigenous education plays a vital role in the transmission of values that Africans consider essential in experiencing life in a holistic way. This is critical to the African's way of life; therefore, indigenous education is not divorced from traditional African religious thought and values. Thus for Africans, the educational institution is not separate from life. There is no distinction between formal, non-formal, and informal education. The entire community is ever engaging in continuous learning and teaching. In this light the Western concept of education does not conform to African reality.

\section{Method}

This research is anchored in the philosophy of phenomenology as established by Husserl (1913) and, the European philosophers Sartre, Heidegger and Merleau-Ponty, who were also in the forefront of phenomenological studies of existence. Phenomenology as defined by Husserl is the study of how people describe things and experience them through their senses. The assumption was we only know what we experience by attending to perceptions and meanings that awaken our consciousness (Patton, 2002). The American psychologist Amedio Giorgio was instrumental in developing empirical phenomenological methods. He defines phenomenology as 'the study of structure and the variations of structure, of the consciousness to which any thing, event or person appears' (Giorgio, 1975, p.72). In phenomenological inquiry the reflection of lived experience is necessarily recollective: it is reflection on experience that is already passed or lived through (Van Manen, 1990, pp. 9-10). Since the purpose of this study is to make meaning out of the lived experiences of the Nigerians living in the United 
State, the phenomenological method was appropriate.

I employed the life history mode of inquiry in conducting interviews and collecting data, and analyzing the psychological meaning of descriptions of lived experiences provided by the participants (Giorgio, 1985; Rossman \& Rallis, 2003). I gathered data from interviews, life histories, participant observation, field notes, and journals. An open-ended question interviewing method was also utilized. This is a well-documented research method that allows the voice of the participant to be heard and helps uncover reality beneath the surface (Riessman, 1993). The data findings were then analyzed through descriptive analysis (Chenail, St. George, Wulff, Duffy \& Charles, 2008; Giorgio, 1975); thematic and connective organization of data and interpretation of results followed (Creswell, 1998; Patton, 2002; Seidman, 2006).

\section{Participants}

Cresswell (1998) states, 'the purposeful selection of participants represents a key decision point in a qualitative study' (p.118). Patton (2002) notes poor sampling may threaten the trustworthiness of the findings; he also suggests that purposeful selection of participants allows the sample to be information rich. The participants consisted of eight Nigerian voluntary immigrant families and their adult children residing in New York, Vermont and Michigan: $(\mathrm{N}=$ twenty, Men $=$ seven, Women $=$ thirteen, including five adult children). The main criterion for participants in the study was that the Nigerian parents be voluntary immigrants and have adult children who have gone through the United States' educational system. The method of selection of the subjects was by 'network' sampling, where one participant leads to another. This method has its strengths and weaknesses. It is not a random sampling technique, and therefore attempts to test hypotheses with statistical measures, and to generalize the findings to a larger population, cannot be done with scientific validity. It is not suitable for statistical analysis, and therefore survey-type questions are inappropriate. The network sampling technique is suitable for interviewing in-depth, observations, case histories, and for life history interviews as used in this study. The method is naturally limited to a small number of subjects.

\section{Results}

Research Question 1: What are Nigerian Voluntary Immigrants' Parental Expectations for their Children's Education?

I have chosen in this section to let the participants speak for themselves, and have selected some of what they say to represent the result of the study. This section touches on participants' experiences as they impact their parental expectations for their children's education and answers research question 1. Parent participants cited many contributing factors based on their culture, including the fact that they themselves have to work hard and the children see them as role models. They expect hard work in return from their children, and they enforce it even more when it comes to their children's education. These parents believe that education is the key to success. They appear not to be seeking perfection or prescribed jobs for their children. They all expressed the desire for a better life for their children than they had had. They wanted the 'American Dream' for their children on the child's own terms. The only stipulation was, whatever they choose to do, they must do well. The participants are represented by their initials rather than giving them pseudo names:

It is all about education, education and education!!! Education is the key to success. I would like them to do better than what I have achieved educationally today. I would like them to get whitecollar jobs. Good paying jobs. I would like them to be lawyers and doctors or simply have good paying jobs. (BM)

His wife, 'AM,' concentrated more on the process and the role of schools in helping children achieve their educational goals: 


\begin{tabular}{|c|c|c|c|c|}
\hline \multicolumn{5}{|c|}{\begin{tabular}{|l|} 
Table 2 \\
Participants' demographic data
\end{tabular}} \\
\hline Letter codes & Age & Education & Occupation & $\begin{array}{l}\text { Length of time in the } \\
\text { United States (years) }\end{array}$ \\
\hline $\begin{array}{l}\text { BM (F) } \\
\text { AM (M) } \\
2 \text { Daughters } \\
1 \text { Son }\end{array}$ & $\begin{array}{l}50 \\
44 \\
19^{\wedge} \text { (in } \\
\text { college), 13, } 17\end{array}$ & $\begin{array}{l}\text { Education } \\
\text { includes post } \\
\text { secondary } \\
\text { school } \\
\text { certifications (F) } \\
\text { Baccalaureate } \\
\text { Teaching } \\
\text { Certification } \\
\text { and other } \\
\text { job specific } \\
\text { certifications } \\
\text { (M) } \\
\end{array}$ & \begin{tabular}{|l} 
Production \\
supervisor (F) \\
Teacher/Social \\
Worker (M)
\end{tabular} & 6 \\
\hline $\begin{array}{l}\text { BE (F) } \\
\text { (Widowed) } \\
4 \text { Daughters }\end{array}$ & $\begin{array}{l}61 \\
32 \wedge \\
30 \\
28 \\
27 \\
\end{array}$ & $\begin{array}{l}* \mathrm{PhD} \\
\wedge * \mathrm{PhD} \\
* \mathrm{MD} \\
\mathrm{BA} \\
\mathrm{BA} \\
\end{array}$ & $\begin{array}{l}\text { State } \\
\text { Bio Engineer } \\
\text { Medical Doctor }\end{array}$ & $\begin{array}{l}38 \\
\text { All children born in US. }\end{array}$ \\
\hline $\begin{array}{l}\text { SB (M) } \\
\text { (Separated) } \\
\text { 1 Daughter }\end{array}$ & $\begin{array}{l}44 \\
17 \\
\end{array}$ & BsN. & Nurse & 1 \\
\hline $\begin{array}{l}\text { BO (M) } \\
\text { O (F) } \\
3 \text { Daughters } \\
\text { Or (18) } \\
\text { EO (29) }\end{array}$ & $\begin{array}{l}53 \\
67 \\
33^{\wedge}, 29, \\
18^{\wedge}\end{array}$ & $\begin{array}{l}* \mathrm{~B} . \mathrm{A} . \\
* \mathrm{RN}, * \mathrm{MS} \\
\wedge * \mathrm{BA}, \mathrm{MA}\end{array}$ & $\begin{array}{l}\text { Business } \\
\text { Anesthetist } \\
\wedge \text { Asian } \\
\text { languages/ } \\
\text { Business }\end{array}$ & $\begin{array}{l}35 \\
40 \\
\text { All children born in US. }\end{array}$ \\
\hline $\begin{array}{l}\text { MU } \\
\text { (Single parent) } \\
3 \text { Daughters } \\
1 \text { Son }\end{array}$ & $\begin{array}{l}60 \\
38,36,26 \\
32 \\
\end{array}$ & $\begin{array}{l}* \mathrm{RN} \\
\text { All are } \\
\text { pharmacists }\end{array}$ & Nurse & $\begin{array}{l}36 \\
\text { All children born in the } \\
\text { US. except the last } \\
\text { daughter. }\end{array}$ \\
\hline $\begin{array}{l}\text { SN } \\
2 \text { Daughters } \\
1 \text { Son }\end{array}$ & $\begin{array}{l}58 \\
23,22, \\
19\end{array}$ & $\begin{array}{l}\text { PhD } \\
\text { (All are in } \\
\text { college) }\end{array}$ & $\begin{array}{l}\text { Consulting } \\
\text { Engineer }\end{array}$ & 18 \\
\hline $\begin{array}{l}\text { OA }(\mathrm{F}) \\
\text { SO (M) } \\
3 \text { Daughters }\end{array}$ & $\begin{array}{l}49 \\
45 \\
19^{\wedge}, 17,14\end{array}$ & $\begin{array}{l}\text { *PhD } \\
\text { *BA } \\
(\wedge \text { In college. })\end{array}$ & $\begin{array}{l}\text { Criminologist } \\
\text { Counselor/ } \\
\text { Social Worker }\end{array}$ & \begin{tabular}{|l|}
25 \\
24 \\
All children born in the \\
US. \\
\end{tabular} \\
\hline $\begin{array}{l}\text { SA } \\
3 \text { sons }\end{array}$ & $\begin{array}{l}55 \\
18,20,21\end{array}$ & $\begin{array}{l}* \mathrm{MD} \\
\text { (All are in } \\
\text { college) } \\
\end{array}$ & Medical Doctor & $\begin{array}{l}4^{8} \\
\text { All children born in the } \\
\text { US. }\end{array}$ \\
\hline $\begin{array}{l}\text { Note. } M=\text { Mot } \\
\wedge=\text { Adult child }\end{array}$ & ther & ree or certifica & n obtained in & United States \\
\hline
\end{tabular}


I expect the school to get them ready for college. Encourage them to study more and know what to do. Teachers should not discourage them by saying that they can't do the work.

It is very important for them to do well because we are a long way from home. We cannot come all these miles to fail. Failure is not an option. (BM)

'SB,' a single mother, and 'BE,' a widower, expressed their expectations as follows:

My expectation was and is that she should go as high as possible with whatever she chooses to do. I would like her to be self-sufficient and not have to depend on her husband financially. (SB)

When I talk about my children, my wife Elizabeth was a key instrument in this. When we started working with our children, there were no plans. Everything was spontaneous. We wanted to give them so much but we had very little. (BE)

Even though 'BE' had said he and his wife had no plans for the children, but as the interview progressed it was apparent that their plans began to enfold. They had successfully raised four girls - a medical doctor, two PhDs, and the last with a Master's degree; all had attended, or were still attending, Ivy League colleges. What is evident in this data is that the parents felt they were doing nothing special to push their children into achieving, and yet their actions and their involvement at home and school appear to have communicated their wishes to the children.

On the question regarding the participants' personal expectations for their own children's education, hard work is the common thread:

He needs to be recognized in a profession so that he can be self-sufficient. I want my children to have no regrets or say, 'I wish I had done this in school' . That is my expectation, nothing more. (BE)

Our expectation in Yoruba culture is for our children to live a better life than us. We want them to be successful, independent, and self-sufficient: to attain an education and to find a good wife or good husband, to have good children, live a good life, and to be able to remember home, where we come from. (SO)

My hard work and the Nigerian experience of hardship have influenced my children. It was a good thing that I relocated them to Nigeria for a period of time. They really got a taste of Nigeria tradition and ways of life. I talk to my children from time to time. I speak to them about men. I tell them if they are educated and self-sufficient they will get more respect from their prospective husband. (MU)

We attend all of their school programs, and encourage them to participate in as much as they can in school-extra-curricular that really has paid off for them...so our expectation of them is simply letting them know that knowledge is power and they have to get good grades. (OA)

Defining achievement for our children. It is about what they learn in the process. Life-long learning is the issue, not grades. The achievement has to be the ability to be a life-long learner. (BO)

I let her know that education is the key to success in life. If she is educated she will get a higher position in life and be respected. If she knows what she is doing, no one can manipulate her. As they say, 'knowledge is power.' She understands my expectations now. (SB)

\section{Conveying Expectations to Children}

Expectations are beliefs that are informed by culture and tradition. How they are conveyed to children is important. In this study it was observed that the parents model the behavior that they want their children to emulate. They also verbalize their hopes and aspirations for the children as often as possible. They support their children's endeavors, sometimes at great length; and they 
provide the children with the environment that nurtures and supports them.

They can see for themselves. Like she says [his wife], there is a lot more opportunity here, and the opportunity is free. When everything that is free, there is a lot of responsibility. We tell our kids, whatever you want to achieve is possible, if you put the effort into it. (OA)

BO: 'We are not rigid; things can change; but the children must give us a plan of action regarding their studies.'

I tell my children about my work situation, and about growing up in Nigeria. I also give them examples of people I know who have done well in life through education. I let them know that I admire those who have succeeded against all odds. (AM)

BM: 'I tell them they have to study hard to make the grade. Success doesn't come without hard work.'

\section{Research Question 2: What Role do Socio-Cultural Contexts Play in Nigerian Parents' Expectations?}

Immigrants' expectations are influenced by personal beliefs and life experiences from their country of origin as well their current home. The new cultural environment usually heightens the expectations of immigrants, bringing up the desires and hopes they nourish and the reasons they moved from their country of origin. Here are excerpts regarding acculturation from some of the participants in this study:

Between the children and us there is a cultural lag. We have to tread lightly or we will lose them. We have to try to accommodate them some because this culture is different from the one we were raised in. For example, one of my friends, Omo e kan dide nle lojo kan lokeru oni ohun nkuro nile nitori Baba ohun ti le ju. [Translation: His daughter decided he was too strict, and left home.]

Omo [Translation: she was] 17 or 18 years in the last year of high school. Baba sun sun sun. Sugbon o pada wa ile. [Translation: Her dad cried and cried - she returned home after a year or so.] She later went to $\mathrm{U}$ of $\mathrm{M}$. That will show you our cultural differences with our children. If we don't manage things very well they will see us as too strict or too mean. These generations are so different from us. I don't know what we can do. But some of us are successful in managing them.

One of the things we did to engrain some of our culture in our children was to send them to Yoruba school here in Michigan. They learned that when they greet me they have to bow as a sign of respect. When they wake up in the morning they must greet me. They cannot just walk through me. (SO)

Parental involvement is extremely important. I am talking about active involvement, like she said [his wife]. So, as you monitor their academic success, you have to monitor their behavior and whom they are socializing with. (OA)

As I studied the data, I came to the understanding that a 'culture of education' runs through the participants' households. This theme was voiced as follows:

I grew up in Nigeria some 55 years ago. I came from a [polygamous] family like most of our communities at home. My parents were influential to my education; they were not only guiding me but also dictating to me as to the importance of education and how important it was to our lives. There were 17 children in the family; my mother had six.

You are the favorite child of the house if you are academically bright. 
You are the favorite son of your mother if you study and do well in your exams, especially for those of us who came from polygamous homes. My father had three wives so it depended on the day we brought our report home that we knew who was a good mother or who was a bad mother. So how you do at school becomes a reflection of your mother in our household.

Effort has a lot to do with educational achievement. (SO)

The participants were asked how experiences from their country of origin helped to form their expectations.

My expectations for their education are culturally induced. It is part of our expectations in Nigeria that our children lived better life than us. We want for them a more peaceful life and a more result-oriented life. (SO)

It's goes back to our culture, too. The Nigerian kids born in America have a conflict of cultures. They have an American mind set and they have a Nigerian mind set. (OA)

In Nigeria, children take their parents' advice and try to live up to that. Of course, in our current environment this is not so. We are faced with a lot of obstacles. This was the Nigerian culture. I grew up with that culture; now here, this is an obstacle. (SB)

\section{Research Question 3: How Have the Second-Generation Adult Children of Immigrants Internalized their Parents' Expectations?}

At the beginning of each interview, I instructed the second-generation participants that I had some questions about their parents' expectations and school achievement. I asked them to feel free to talk about anything, and that our interviews were not meant to judge; rather, they were a way to triangulate their parents' role in helping them to achieve academic success. Below are some of the responses:

Basically, in anything we do they just want us to try our hardest, no matter what we do. It's never really been about the grades, but the effort. I always know I have to try my hardest, not that I always do. If they notice that I don't, that's when the problems occur. This is my third semester in the university. Last semester I got one $C_{+}$. It was never an issue about the $C_{+}$as far as that I tried hard enough, but what my problem is. Whenever they ask about school, I tell them one class is giving me problems. So, even though I got a C+, it didn't bother them because I was telling them why. I am typically an A student, but when I do have a bad grade, it's never about the bad grade but how much effort. (LO)

They have explained to me that in order to succeed in this world, you need to work hard academically and it is completely up to me to decide my path of success. My parents explained to me that when they went to school, it was extremely difficult for them and that I should appreciate that due to the changing times I should fully utilize all of the resources provided for me. They continued, that with hard work come great rewards. I did not acknowledge this at first, but when I started school I realized that people that worked hard in school received things such as certificates and other awards. Knowing this, I wanted to not only make my parents proud, but myself as well. Receiving awards only proves that the hard work one invests is being recognized. (WM)

Education was a priority. I don't think it was explicit. They were not telling me that you have to study and get all A's and stuff. It was more just implicit. I don't think I remember ever been told. They had high expectations.

I was self-motivated. I never needed intervention; I studied on my own.

I don't think it was ever an issue in high school. But in college, there was pressure to get into a more technical field. I was an engineer. I remember thinking that I just wanted to do business, but I remember my mom saying: "No, you need to go into engineering." And I could remember my dad 
saying: 'let her do whatever she wants'.

I guess it wasn't like such a big deal to me so I did engineering [laughs]. Now I am back to business. I will be done with my MBA in June. (NO)

Education was priority number one as far as our parents were concerned. Education was the most important thing for us. We had to perform well in school. If we had any problems at school, our parents would always come to the school to talk to our teachers. They tried to make sure that we could improve our performance and to know what was holding us back. By the end of every school year we were performing on top for the most part. (EE)

I think my parents' expectations for me was just right. They praised me when I did well, and they understood when I do badly. It's never been an issue. They always understand. I think I'm harder on myself than they are. On a personal level, I always want to do well. I think I'm harder on myself. Our expectation is similar. I always attend classes and try my hardest. (LO)

The expectations that I have for myself may be a little bit greater than that of my parents because I want to be able to go above and beyond my elements. (WM)

I would say my parents' expectations for me were just right. As far as I can remember from kindergarten, if we did well on a project our parents would give us a sticker or put our names on a board where everyone could see it; that always felt good. As a young person, I wanted to do well and my parents wanted me to do well. They had high expectations for us but they went about it in an encouraging way. Even though their expectations were too high they were encouraging.

I think they (parents) always wanted more. They always yelled at us, 'do this do that!' They wanted us to do excellent work at school. And when they had guests they were always bragging about how well we were doing. I would say to myself, 'They are bragging now, and when the guests leave and we slip in any way, we are going to be in trouble.' The problem is that once you have achieved a goal they set for you, they set another one. It is never ending. You feel like you will never satisfy them. There is always more that can be done. (EE)

\section{Discussion and Conclusion}

\section{Parental Expectations and Academic Achievement}

Parental expectations of the participants for their children's education in the United States, as evidenced by interview responses, developed over time and are rooted in their Nigerian upbringing and culture, overlaid with their adaptation to their new American culture. Participants' responses give credence to my developing theory that the parental expectations for their children's academic achievement in the US come about through a blend of cultures. The second-generation have a conflict of cultures. (OA): 'They (the children) have an American mind set and they (the parents) have a Nigerian mind set.'

All participants indicated they had demanding jobs that helped them care for their families. It is evident from this study and those reviewed earlier, that achievement is related to socioeconomic status, as well as parental involvement. Demographic data of the participants (see table 2) indicate that that they are middle class. All had to work hard to attain this status and they commented that they did so to make sure that their children had a good education; a few moved into the suburbs where there were better schools.

All parents mentioned that they were involved with their children's homework assignments when they were young; as the children grew they became more independent, needing their parents' direct help on homework assignments less and less. Meanwhile, the 'homework ethic' had been fully ingrained in all the students, and this translated to success in school. Parents reported that all 
their children are self-motivated because they had taken the time to do the necessary groundwork while the children were small. They maintained discipline, gave them love, and showed them how to achieve success through their own hard work and the telling and retelling of stories about family members and friends who had done well through education.

The parents interviewed not only expect that children rise to their expectations; they also enabled the children in these endeavors. 'AM' (a parent) notes:

I help them meet my expectations by helping them get to school on time, and being supportive of their educational endeavors. I get in contact with teachers often to build relationships with them.

The narratives from the participants indicate that Nigerian values drive the responses. Achievement is defined as not only getting good grades, but in becoming a respected citizen of good character. 'HO' states:

Defining achievement for our children is very simple for us. If they have done the best they can, then they have succeeded. It is not about grades; it's about what they learn in the process.

Among the many factors that were credited with helping their children succeed, the parents reported that they closely monitored their children's school work, made sure they did their homework, and encouraged them to make good friends and to associate with people who were likely smarter than themselves.

The study reveals that the primary objective of the parents is defining achievement for their children. Once this foundation has been laid, parents then proceed to leverage their means of communicating with and supporting their children in school and in the community. The results also indicate that immigrant Nigerian parents have successfully transmitted to their offspring a specific value-system that they believe influenced their children's educational attainment.

\section{The Socio-Cultural Context of Parental Expectations}

Based on the reports from participants, traditions from the Nigerian culture have not been lost in the parenting of the children. According to Yoruba tradition, a person's life is guided by the concept of 'omoluabi' or 'personhood,' meaning one is not a human being just because s/he was born. You have to earn the right to personhood. How you do this is by proving yourself on several levels, including hard work, succeeding in whatever vocation you choose, and emphasizing the importance of family ties and obligations. The Yoruba tradition expectation stipulates that one is responsible for one's brothers and sisters and they are obligated to reciprocate in return. In Nigeria- there is no welfare system; the family and the community are responsible for each other's welfare. As reflected in the responses of the participants, indigenous education is a process that starts at birth and is continuous until death. Learning is inseparable from the people's daily lives. When things began to change in Nigeria due to the arrival of Western education, many parents saw to it that their children upheld the new cultural values while respecting the indigenous values; a new way of becoming an 'omoluabi' was born.

In reviewing the participants' responses it is evident they have been substantially influenced by the Nigerian heritage as well as American culture. There are connecting threads through the three generations (grandparents in Nigeria, their children as the participants in this study, and the grandchildren, most of whom were born in the United States, and all were educated in the US). Among the responses of the grandchildren in the United States we can identify commonality with the grandparents in Nigeria. Common characteristics include: 'education is the priority, 'hard work,' 'high expectations,' 'do the best you can,' and 'support and encouragement from the family.'

Berry (1997) hypothesized that regarding acculturation strategies in plural societies, cultural groups 
and the individual members in both dominant and non-dominant situations must grapple with the issue of how to acculturate. Strategies to navigate these issues are usually a dance between cultures and the people involved. This is borne out by the expressed feelings of the participants in this study. Berry continues:

The issues involved are cultural maintenance (to what extent are cultural identity characteristics considered to be important and their maintenance strived for); and contact and participation (to what extent should they become involved in other cultural groups, or remain primarily among themselves) (p. 9).

The participants in this study have chosen an integration option of acculturation (Berry), which is to participate in the larger network of their new country by doing what it takes within the boundaries of their original country's culture dictum. They are maintaining active interests in both the original culture (Nigeria) as well as participating fully in the new culture's larger society.

\section{Second-Generation Internalization of their Parents' Expectations}

A number of factors are identified which bear on the performance of the immigrants' children born and educated in the United States. All the children in the study were high achievers in US schools, up through their college and postgraduate years. All are from educated families (See table 2 for education status of participants). These factors and the informal and common sense beliefs or folk theory (Furnham, 1988) of the parents shape these families and their realities. The characteristics of American culture that support academic achievement include progressive school programs, extracurricular activities, educational resources, opportunities for women, college financial aid, a laissez-faire mode of child rearing, and opportunities for choices in education and career. Although cultural conflicts exist, they are usually resolved. On the issue of second-generation children's internalization of their parents' expectations, they unanimously believe that they agree with their parents' expectations, even though it was hard at times to conform to them.

\section{Research Limitations}

In qualitative study, the researcher is an instrument of data collection (Rossman \& Rallis, 2003; Patton, 2002). This can be an asset as well as a limitation. The choice of data collection strategies may lessen the likelihood that this research can be generalized to all Nigerian groups, let alone Africans as a whole. The number of participant is small; this is in keeping with most qualitative studies. Thus, this research is exploratory and will lead to additional questions and directions of study. A quantitative study of this subject is highly encouraged. A quantitative or qualitative study on the subject may also be carried out with non-voluntary immigrant population who are not the subject of this study.

\section{REFERENCES}

African immigrants in the United States are the most highly educated group. The Journal of Blacks in Higher Education, Winter, 1999-2000, 26, pp. 60-61.

Alspaugh, J. (1998). Achievement loss associated with transition to middle school and high school. Journal of Educational Research, 92(1), pp, 20-25.

Alspaugh, J., \& Harting, R. (1995). Transition effects of school grade level organization on student achievement. Journal of Research and Development in Education, 28(3), pp. 145-149.

Becher, R. M. (1984). Parent involvement: A review of research and principles of successful practice. Washington, DC: National Institute of Education.

Berry, J. W. (1997). Immigration, acculturation and adaptation. Applied Psychology: An International Review, 46(1), pp. 5-68.

Bourdieu, P. (1977a). Cultural reproduction and social reproduction. In Karabel, J. \& Halsey, A. H., eds. (1977), pp. $487-510$.

Bourdieu, P., \& Passeron, J. C. (1977). Reproduction in education, society, and culture. Beverly Hills, CA: Sage Publications. 
Carden, D.L. (2005) Parental Expectations and the role of parent involvement in an independent school. Ed.D. Dissertation, The University of Alabama.

Chen, C., \& Stevenson, H. W. (1995). Motivation and mathematics achievement: A comparative study of Asian-American, Caucasian-American, and East Asian high school students. Child Development, 66(4), pp. 1215-1234.

Chen, X. (1996). Educational achievement of Asian American students: A generational perspective. Unpublished Doctoral Dissertation, University of Michigan .

Chenail, R. J., St. George, S., Wulff, D., Duffy, M., \& Charles, L. L. (2008). The Qualitative Report [Online]. (Retrieved April 27, 2008) (URL: http://www.nova.edu/ssss/QR/index.html).

Creswell, J. W. (1998). Qualitative inquiry and research design: Choosing among five traditions. Thousand Oaks, CA: Sage Publications.

Desimone, L. (1999). Linking parent involvement with student achievement: Do race and income matter? The Journal of Educational Research, 93(1), p. 11.

Eccles, J. S., \& Harold, R. D. (1993). Parent-school involvement during the early adolescent years. Teachers College Record, 94(3), pp. 568-587.

Eccles, J., Wigfield, A., Midgley, C., Reuman, D., Maclver, D., \& Feldlaufer, J. (1993). Negative effects of traditional middle schools on students' motivation. Elementary School Journal, 93(5), pp. 553-574.

Englund, M. M., Luckner, A. E., Whaley, G. J. L., \& Egeland, B. (2004). Children's achievement in early elementary school: Longitudinal effects of parental involvement, expectations, and quality of assistance. Journal of Educational Psychology, 96(4), pp. 723-730.

Epstein, J. (1995). School-family-community partnerships: Caring for the children we share. Phi Delta Kappan, 76, pp. 701-712.

Ethington, C. A. (1991). A test model of achievement behaviors. American Educational Research Journal, 28(1), pp. 155-172.

Foner, N. ed. (2009) . Across generations: Immigrant families in America. New York: New York University Press. Foner, N. (2009a). Intergenerational relations in immigrant families in Foner, N. (2009).

Fordham, S. \& Ogbu, J. (1986) Black students' school success: coping with the burden of acting White, The Urban Review, 18(3), pp. 176-206.

Furnham, A. (1998). Lay theories: Everyday understanding of problems in the social sciences. Oxford: Pergamon Press.

Giorgio, A. Fischer, C. \& Murry, E. L. eds. (1975). Duquesne studies in phenomenological psychology: Vol.2.

Pittsburgh, PA: Duquesne University Press.

Giorgio, A. (1975). Convergence and divergence of qualitative methods in psychology. In Giorgio, A. Fischer, C. \& Murry, E. L. eds. (1975), pp.72-79.

Giorgio, A. ed. (1985). Phenomenology and psychology research. Pittsburgh, PA: Duquesne University Press. Halle, T., Kurtz-Costes, B., \& Mahoney, J. (1997). Family influences on school achievement in low-income African American children. Journal of Educational Psychology, 89(3), pp. 527-537.

Husserl, E. (1913). Ideas. London: George Allen and Unwin. Republished 1962. New York: Collier.

Johnson, J. B. (2005, February 22). Shades of gray in Black enrollment: Immigrants rising numbers a concern to some activists. San Francisco Chronicle.

Karabel, J. \& Halsey, A. H., eds. (1977). Power and ideology in education. New York: Oxford University Press. Kim, C. (2004). Imagining race and nation in multiculturalist America. Ethnic and Race Studies, 27, pp. 9871005.

Le, C.N. (2007). Demographic characteristics of immigrants Asian-Nation: The landscape of Asian America.

[Online]. (Retrieved June 26, 2007) (URL: http://www.asian-nation.org/immigrant-stats.shtml)

Lee, S. (1994). Family-school connections and students' education: Continuity and change of familyinvolvement from the middle grades to high school. Baltimore, MD: The Johns Hopkins University Press.

$\mathrm{Li}, \mathrm{J}$. (2004). Parental expectations of Chinese immigrants: A folk theory about children's school achievement. Race, Ethnicity and Education, 7(2),pp. 167-183).

Losh, S.C. \& Tavani, C.M. (2003). Motivation, self-confidence and expectations as predictors of the academic performances among our high school students. Child Study Journal, 33(3), pp. 141-151.

Mbiti, J. S. (1990). African religions and philosophy. 2nd ed. New Hampshire: Heineman.

Menkiti, I. A. ed. (1984). Person and community in African traditional thought. In Wright, R. A. ed. (1984), pp.171-182.

Moss, E., \& St. Laurent, D. (2001). Attachment at school age and academic performance. Developmental Psychology, 37(6), pp. 863-874. 
Muller, C. (1993). Parent involvement and academic achievement: An analysis of family resources available to the child. In Schneider, B. \& Coleman, J. S. eds. (1993), pp. 77-114.

Ogbu, J. U. (1995). Cultural problems in minority education: Their interpretations as consequences-part one: Theoretical account. The Urban Review: Issues and Ideas in Public Education, 27(3), pp. 189-205.

Onwauchi, P. C. (1972). African peoples and western education. The Journal of Negro Education, 41(3), pp. 241247.

Patrikakou, E. N. (1997). A model of parental attitudes and the academic achievement of adolescents. Journal of Research \& Development in Education, 31(1), pp. 7-26.

Patton, M.Q. (2002). Qualitative research \& evaluation methods, 3rd ed. London: Sage Publications.

Pearce, R., \& Lin, Z. (2005). Cultural capital and postsecondary educational attainment among White and Chinese Americans: An analysis of NELS 1988-2000. Asian American Policy Review, 4, pp. 19-37.

Pearce, R. R. (2006). Effects of cultural and social structural factors on the achievement of White and Chinese students at school transition points. American Educational Research Journal, 43(1), pp. 75-101.

Portes, A. \& Rumbaut, R.G. (2001). Legacies: The story of the immigrant second generation. Berkeley, CA: University of California Press.

Portes, A. \& Rumbaut, R.G. (1990). Immigrant America: A portrait. Berkeley, CA: University of California Press. Portes, R. R., \& Zady, M. F. (1996). Socio-psychological factors in the academic achievement of children of immigrants: Examining a cultural history puzzle. American Educational Research Journal, 36, pp. 489-507. Rimmer, S., \& Arenson, K. W. (2004). Top colleges take more Blacks, but which ones? The New York Times on the Web. [Online]. (Retrieved June 24, 2007) (URL: Http://www.uh.edu/ednews/2004/ nytimes/200406/20040624harvard.html.)

Riessman, C.K. (1993). Narrative Analysis. Newbury Park, CA: Sage Publications.

Rossman, G.B. \& Rallis, S.F. (2003). Learning in the field: An introduction to qualitative research. London: Sage Publications.

Schneider, B. \& Coleman, J. S. eds. (1993). Parents, their children, and schools. Boulder, CO: Westview. Seginer, R. (1983). Parents' educational expectations and children's academic achievement: A literature review. Merrill-Palmer Quarterly, 29(1), pp. 1-23.

Seidman, I. (2006). Interviewing as qualitative research: A guide for researchers in education and the social sciences. 3rd ed. New York: Teachers College Press.

Sowell, T. (1981). Ethnic America. New York: Basic Books.

Stevenson, D. L., \& Baker, D. P. (1987). The family-school relation and the child's school performance. Child Development, 58(5), pp. 1348-1357.

Stevenson, H., \& Lee, S. (1990). Contexts of achievement. Monographs of the Society for Research in Child Development, 55(1-2), pp.i-119.

Sui-Chu, E. H., \& Williams, J. D. (1996). Effects of parent involvement on eighth-grade achievement. Sociology of Education, 69(2), pp. 126-141.

Tedla, E. (1992). Indigenous African education as a means for understanding the fullness of life: Amara traditional education. Journal of Black Studies, 23(1), pp. 7-26.

U.S. Census Bureau. (2000). Statistical Abstract of the United States: 2006. Washington DC: United States Department of Commerce.

Van Manen, M. (1990). Researching lived experience: Human science for an action sensitive pedagogy. New York: State University of New York Press.

Waters, M. (2000). Black identities: West Indian immigrant dreams and American realities. Cambridge, MA: Harvard University Press.

Waters, M.C. \& Sykes, J.E. (2009). Spare the rod ruin the child? First and second generation West Indian child rearing practices in Foner, N., ed. (2009), pp. 72-97.

Wiredu, J. E. (1977). How not to compare African traditional thought with Western thought. Transition, 75/76, pp. 320-327.

Wolf, A. (2007). Skin color and salary: Lighter and taller equals a bigger paycheck for immigrants, study says. [Online]. (Retrieved June 24, 2007) (URL: http://www.vanderbilt.edu/register/articles?id=31710)

Wright, R. A., ed. (1984) African philosophy: An introduction. 3rd ed. Lanham, MD: University Press of America.

Zhou, M. (2009). Conflict coping and reconciliation: Intergenerational relations in Chinese immigrant families in Foner, N., ed. (2009), pp. 21-46. 